\title{
Storage of Blood Components Does Not Decrease Haemostatic Potential: In vitro Assessment of Fresh versus Stored Blood Components Using Thromboelastography
}

\author{
Galia Bartfeld ${ }^{a, b^{*}}$ \\ Martin Ellis ${ }^{b, c^{*}}$ \\ Aharon Lubetzky,d \\ ${ }^{a}$ Department of Internal Medicine B, Meir Medical Centre, Kfar Saba, \\ ${ }^{\mathrm{b}}$ Sackler School of Medicine, Tel Aviv University, Tel Aviv, \\ ${ }^{c}$ Haematology Institute and Blood Bank, Meir Medical Centre, Kfar Saba, \\ ${ }^{\mathrm{d}}$ Thrombosis and Haemostasis Unit, Sheba Medical Centre, Tel Hashomer Hospital, \\ ${ }^{e}$ National Blood Services, Magen David Adom, Tel Hashomer Medical Centre, Ramat Gan, Israel
}

Vered Yahalom ${ }^{\mathrm{b}, \mathrm{e}}$

Gili Kenet ${ }^{\mathrm{b}, \mathrm{d}}$

\section{Keywords}

Rotational thromboelastography . Stored blood products . Haemostatic properties

\section{Summary}

Background: Major surgery and severe trauma typically lead to massive blood loss requiring rapid transfusion of large amounts of blood products. It has been suggested that fresh, unrefrigerated whole blood provides a haemostatic advantage in this setting. The aim of the current study was to compare the clot formation parameters of fresh, unrefrigerated whole blood and whole blood reconstituted from components stored for varying periods of time, using rotational thromboelastography $\left(\right.$ ROTEM $\left.^{\circledR}\right)$. Methods: Fresh whole blood and reconstituted whole blood using combinations of nonleucoreduced red cell units (stored for $7,14,21,28$, or 35 days), platelet concentrates (stored for 1,3 or 5 days), and fresh frozen plasma (stored for 6 months) were analysed using ROTEM. Measurements of the clotting time (CT), clot formation time (CFT), and maximal clot firmness (MCF) were compared between units of fresh whole blood and reconstituted whole blood samples. Results: There was no difference in the haemostatic parameters measured of fresh whole blood and reconstituted whole blood using red cell units stored for less than 21 days. ROTEM demonstrated that the CT and CFT were significantly shorter for reconstituted whole blood samples using red cells stored for longer than 21 days when compared to fresh whole blood and to reconstituted whole blood samples using red cell units stored for less than 21 days. The CT was inversely correlated to the duration of platelet storage. The MCF was unchanged regardless of duration of blood product storage. Conclusion: Fresh unrefrigerated whole blood and blood products stored for short duration (less than 21 days) were not superior to those stored for longer durations.

\footnotetext{
* These authors contributed equally to this work.
}

\section{Schlüsselwörter}

Rotationsthrombelastographie · Gespeicherte Blutprodukte Hämostatische Eigenschaften

\section{Zusamenfassung}

Hintergrund: Große chirurgische Eingriffe und schwere Traumen führen meist zu massivem Blutverlust, der eine schnelle Transfusion groBer Mengen von Blutprodukten erfordert. Bisher wurde vermutet, dass unter diesen Bedingungen frisches, nichtgefrorenes Vollblut Vorteile in Bezug auf die hämostatischen Eigenschaften mit sich bringt. Das Ziel der vorliegenden Studie war es, die Parameter der Gerinnselbildung von frischem, nichtgefrorenem Blut mit denen von Vollblut, das aus verschiedenen unterschiedlich lang gelagerten Komponenten wieder zusammengesetzt wurde, mit Hilfe der Rotationsthrombelastographie $\left(\right.$ ROTEM $\left.^{\circledR}\right)$ zu vergleichen. Methoden: Frisches Vollblut und unter Zuhilfenahme von nichtleukoreduzierten Erythrozytenkonzentraten (gelagert für 7, 14, 21, 28, bzw, 35 Tage), Thrombozytenkonzentraten (gelagert für 1, 3 bzw. 5 Tage) sowie frisch gefrorenem Plasma (gelagert für 6 Monate) wieder zusammengesetztes Vollblut wurden mit Hilfe von ROTEM untersucht. Die Gerinnungszeit (clotting time; CT), die Gerinnselbildungszeit (clot formation time; CFT) und die maximale Gerinnselfestigkeit (maximal clot firmness; MCF) von Einheiten frischen Vollbluts und wieder zusammengesetzten Vollblutproben wurden verglichen. Ergebnisse: In Bezug auf die hämostatischen Parameter gab es keine Unterschiede zwischen frischem Vollblut und wieder zusammengesetztem Vollblut, bei dem die Erythrozytenkonzentrate nicht länger als 21 Tage gespeichert worden waren. Die ROTEM-Analyse zeigte, dass sowohl die CT als auch die CFT für wieder zusammengesetztes Vollblut, bei dem die roten Blutzellen länger als 21 Tage gespeichert waren, signifikant kürzer waren als bei frischen Vollblut oder wieder zusammengesetztem Vollblut, bei dem die roten Blutzellen weniger als 21 Tage gelagert waren. Die CT war invers mit der Dauer der Thrombozytenlagerung korreliert. Die MCF war unverändert, unabhängig von der Dauer der Blutproduktelagerung. Schlussfolgerung: Frisches nichtgefrorenes Vollblut und Blutprodukte, die für kürzere Zeit gelagert waren (weniger als 21 Tage) sind Blutprodukten, die längere Zeit gelagert waren, nicht überlegen.

\begin{tabular}{ll}
\hline KARGER & ( 2010 S. Karger GmbH, Freiburg \\
$\begin{array}{l}\text { Fax +497614520714 } \\
\text { Information@Karger.de } \\
\text { www.karger.com }\end{array}$ & $\begin{array}{l}\text { Accessible online at: } \\
\text { www.karger.com/tmh }\end{array}$
\end{tabular}

\section{KARGER}

Accessible online at:
Dr. Martin Ellis

Haematology Institute and Blood Bank

Meir Medical Centre

59 Tchernichovsky Street, Kfar Saba 44281, Israel

Tel. +972 $97471-045$, Fax -295

martinel@clalit.org.il 


\section{Introduction}

Major surgery and severe trauma often result in massive blood loss. Assessment of the efficacy of the haemostatic system is crucial in the treatment of these patients who invariably receive large numbers of blood products. Some authorities claim that, in the setting of trauma or surgical bleeding, the transfusion of fresh unrefrigerated whole blood or red cells not subjected to prolonged blood bank storage is preferable to the transfusion of products stored for longer periods of time $[1,2]$, while others refute this contention $[3,4]$.

Thromboelastography (TEG) is a technique that has been used predominantly in surgical patients to demonstrate the kinetics of clot formation and dissolution and to document the viscoelastic properties of the clot [5, 6]. It may be used to assess abnormalities in clot production and stability and may help determine their cause. TEG operates using whole blood and its underlying principle is the transformation of the viscoelastic properties of the blood into electrical signals that are captured and recorded graphically. TEG is a promising tool in the evaluation of clot formation in haemophilia and rare bleeding disorders as well as in hypercoagulable states [7, 8]. Individual patient responses to administration of haemostatic compounds, for example bypassing agents, may also be evaluated by TEG, but its clinical relevance in this context requires further investigations $[9,10]$.

In this study, we compared clot formation parameters (tested by ROTEM) using either fresh whole blood or whole blood reconstituted from components stored for varying lengths of times according to standard blood bank protocols.

\section{Material and Methods}

Fresh, (<24 h after donation) unrefrigerated whole blood units and reconstituted whole blood samples were analysed. The reconstituted samples were comprised of packed red blood cells (PRBCs) stored at $1-6{ }^{\circ} \mathrm{C}$ for either $7,14,21,28$ or 35 days which were mixed with whole blood platelets stored for either 1,3 or 5 days at $20-24^{\circ} \mathrm{C}$ on a horizontal shaker and additional fresh frozen plasma (FFP) stored at $-30{ }^{\circ} \mathrm{C}$ for 6 months. Whole reconstituted blood samples were prepared by mixing $5-5.5 \mathrm{ml}$ of PRBCs with 1-1.5 ml platelet concentrate and 3-4 ml of FFP, to achieve a total final volume of $10 \mathrm{ml}$. A complete blood count was performed on the samples (Advia Hematology System, Bayer, Leverkusen, Germany). When necessary, the component proportions were adjusted to obtain normal haematocrit (38-46\%) and platelet counts (150 000-400 000/ $\mu \mathrm{l})$. A total of 5 different blood products (reconstituted and fresh whole blood) from each time point were analysed.

All blood units were type O, non-leucoreduced, and obtained and prepared using standard blood bank techniques. Donors signed an informed consent, and the Meir Medical Centre Ethical Committee approved the study.

Whole blood clot formation and stability were evaluated by TEG studies, using ROTEM ${ }^{\circledR}$ (Tem International GmbH, Munich, Germany). In this system, clot formation in the sample leads to impedance of a pin on a rotating shaft $\left( \pm 4.75^{\circ}\right.$; cycle time $\left.10 / \mathrm{s}\right)$. The resultant change in shaft rotation during clotting is detected via reduced elasticity between the pin and a connected spring [11]. Prior to analysis, citrated whole blood $(300 \mu \mathrm{l})$ was incubated for $2-5 \mathrm{~min}$ at $37^{\circ} \mathrm{C}$; and $20 \mu \mathrm{l}$ standard reagent (NATEM, Pentapharm, Munich, Germany) were added to the TEG cups to initiate haemostasis via the extrinsic pathway (this test is a modification of the EXTEM reagent, used by Pentapharm). NATEM is a $0.2 \mathrm{mmol} / \mathrm{l}$ solution of $\mathrm{CaCl}_{2}$ obtained using calcium chloride and Hepes buffer $(0.02 \mathrm{~mol} / \mathrm{l}$ Hepes, $0.2 \mathrm{~mol} / 1$ calcium chloride, $\mathrm{pH} 7.4$ ), either alone or in combination with $20 \mu \mathrm{l}$ tissue factor (TF; Innovin, Dade-Behring, Marburg, Germany), diluted 1:2,500 to a final concentration of 1:42,500 (approximately $5 \mathrm{pg} / \mathrm{ml}$ or $0.14 \mathrm{pmol} / \mathrm{l})$. Other evaluations were performed using NATEM and INTEM (Instrument Laboratory, Barcelona, Spain) - a partial thromboplastic phospholipid reagent derived from rabbit brain (phospholipid reagent was lyophilized Silica). Analyses were performed using the plastic cups provided by the manufacturer. All samples were run in a total volume of 320-340 $\mu \mathrm{l}$ for $2 \mathrm{~h}$ to enable a full thromboelastogram assessment. The pattern of clot formation and measurements of clotting time (CT), clot formation time (CFT), and maximal clot firmness (MCF) were done. CT describes the latency time from the start of analysis until initial clot formation; CFT is the time from initial clot formation until a fixed clot strength (20 mm amplitude in the thromboelastogram); and MCF denotes the maximum amplitude, indicative of the maximum clot strength.

ROTEM results are presented as average values calculated from triplicate measurements.

Statistical analysis was performed using SSPS ${ }^{\circledR}$ for Windows, version 11.5 (Chicago, Il, USA). Blood products were compared using analysis of variance (ANOVA) for parametric data and the Kruskall-Wallis test for non-parametric data. A p value of $<0.05$ was considered significant.

\section{Results}

A total of 88 samples were analysed in triplicate. Of these, 15 were samples obtained from fresh whole blood units, 13 were from PRBCs stored for 7 days, 16 from PRBCs stored for 14 days, 14 from PRBCs stored for 21 days, 15 from PRBCs stored for 28 days, and 15 from PRBCs stored for 35 days. Platelets used to reconstitute whole blood were derived from either fresh platelet units $(\mathrm{n}=15)$ or platelet units stored for 1 $(\mathrm{n}=25), 3(\mathrm{n}=27)$ or $5(\mathrm{n}=21)$ days.

The CT results using NATEM are summarised in table 1 and displayed in fig. 1 . The CT for reconstituted blood with platelets stored for 1 day and PRBCs stored for 7 days was $722.2 \pm 107.4 \mathrm{~s}$, compared to $504.0 \pm 155.4 \mathrm{~s}$ for platelets stored for 5 days and PRBCs stored for 35 days. The CT obtained for fresh blood was $635.2 \pm 129.1 \mathrm{~s}$. There was no statistically significant difference between the CT obtained using fresh whole blood and that obtained using PRBCs stored up to 14 days. When PRBCs stored for longer than 14 days were used, the CT shortened significantly ( $p<0.0001)$. The CT shortened as a function of platelet age in a statistically significant manner $(\mathrm{p}<0.0001)$.

There was no difference in CFT when fresh whole blood and packed cells stored up to 14 days were compared $(\mathrm{p}=0.2)$. The CFT for reconstituted blood with platelets stored for 1 day and PRBC stored for 7 days was $243.4 \pm 85.5$ s, compared to $168.0 \pm 63.6 \mathrm{~s}$ for platelets stored for 5 days and PRBC stored for 35 days. The CFT obtained when fresh blood was studied was $148.2 \pm 21.6 \mathrm{~s}$. When PRBCs stored for longer than 14 days were used, the CFT shortened significantly 


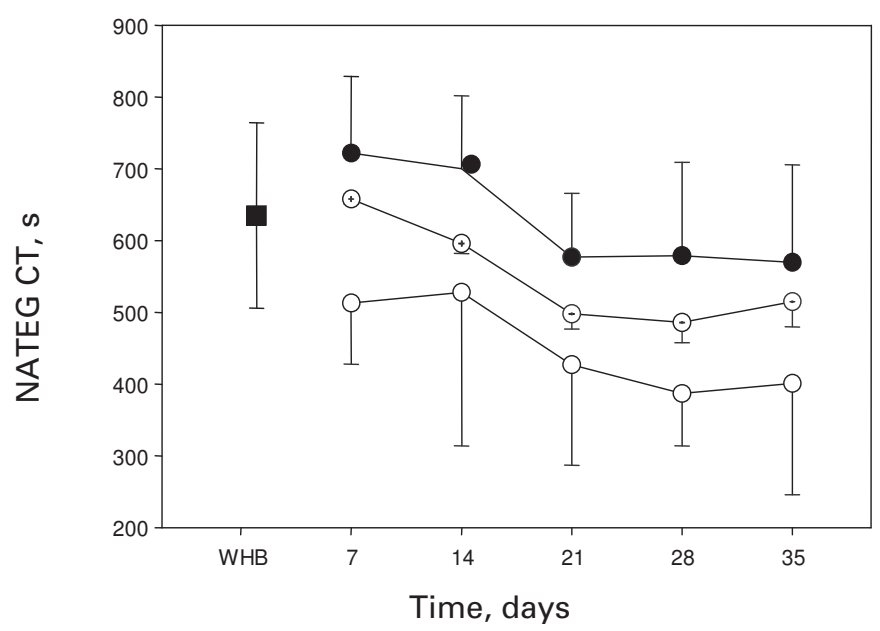

Fig 1. CT results obtained using NATEM. WHB is fresh, unrefrigerated whole blood (full square), full circles designate reconstituted whole blood using platelets stored for 1 day, circles with dot designate reconstituted whole blood using platelets stored for 3 days and empty circles designate reconstituted whole blood using platelets stored for 5 days. The $\mathrm{X}$-axis shows the duration of storage of PRBC units used to reconstitute whole blood.

There was no statistically significant difference between the CT obtained usingfresh whole blood and packed cells aged up to 14 days. When packed cells stored for longer than 14 days were used, the CT decreased significantly $(\mathrm{p}<0.0001)$. The CT decreases as a function of platelet age in a statistically significant manner $(\mathrm{p}<0.0001)$.

( $\mathrm{p}<0.0001)$ (but it was shortest at 14 days). The CFT was not affected by the duration of platelet storage (table 2, fig. 2).

There was no difference in MCF between fresh whole blood and reconstituted whole blood irrespective of the duration of storage of either PRBCs or platelets. The MCF for reconstituted blood with platelets stored for 1 day and PRBCs stored for 7 days was $63.5 \pm 6.2 \mathrm{~mm}$, compared to $58.1 \pm 3.9$ $\mathrm{mm}$ for platelets stored for 5 days and PRBCs stored for 35 days. The MCF obtained when fresh blood was studied was $63.3 \pm 4.3 \mathrm{~m}$ (table 3$)$.

The CT results using modified EXTEM are summarised in table 4. The CT for reconstituted blood with platelets stored for 1 day and PRBCs stored for 7 days was $405 \pm 92.4$ s, compared to $218.5 \pm 55.1 \mathrm{~s}$ for platelets stored for 5 days and PRBCs stored for 35 days. The CT obtained when fresh blood was studied was $409.6 \pm 80.9$ s. There was no statistically significant difference in CT values regardless of fresh or reconstituted whole blood was used.

Likewise, there was no difference between the CFT obtained using fresh whole blood and that found with reconstituted whole blood. The CFT for platelets stored for 1 day and PRBCs stored for 7 days was $120.5 \pm 29.3 \mathrm{~s}$, compared to $125.6 \pm 36.7 \mathrm{~s}$ for platelets stored for 5 days and PRBCs stored for 35 days (table 5). The CFT obtained when fresh blood was studied was $119.6 \pm 11.5 \mathrm{~s}$.

There was no difference in MCF between fresh whole blood and reconstituted whole blood when using EXTEM.

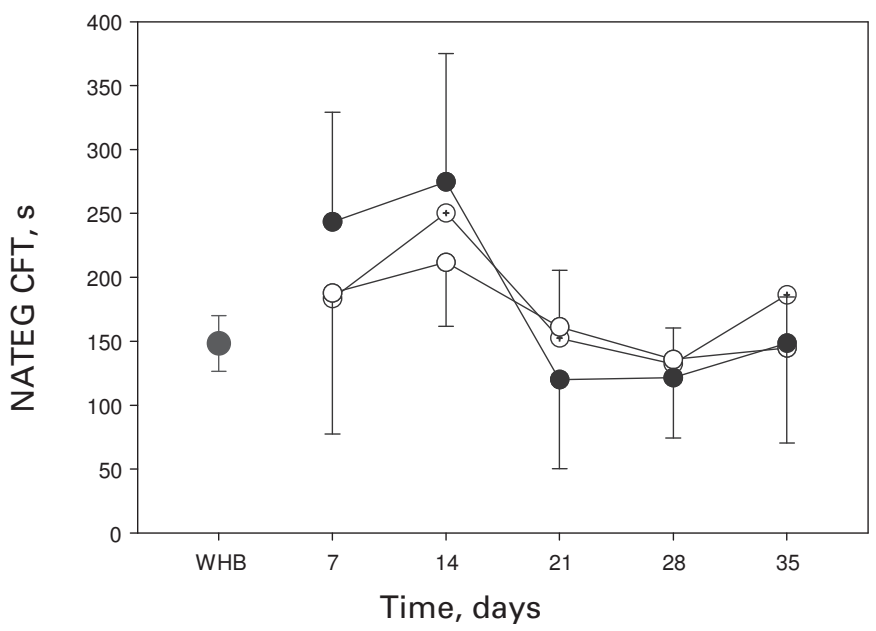

Fig 2. CFT results obtained using NATEM. WHB designates fresh, unrefrigerated whole blood (single full circle), full circles designate reconstituted whole blood using platelets stored for 1 day, circles with dot designate reconstituted whole blood using platelets stored for 3 days and empty circles designate reconstituted whole blood using platelets stored for 5 days. The $\mathrm{X}$-axis designates the duration of storage of red cell units used to reconstitute whole blood.

There was no statistically significant difference between the CFT obtained using fresh whole blood and packed cells stored up to 14 days. When packed cells stored for longer than 14 days were used, the CFT shortened significantly $(\mathrm{p}<0.0001)$. The CFT was not affected by the duration of platelet storage.

The MCF for reconstituted blood with platelets stored for 1 day and PRBCs stored for 7 days was $69.0 \pm 3.0 \mathrm{~mm}$, compared to $58.3 \pm 4.2 \mathrm{~mm}$ for platelets stored for 5 days and PRBCs stored for 35 days. (table 6) The MCF obtained when fresh blood was studied was $63.7 \pm 3.6 \mathrm{~mm}$.

The CT results using INTEM are summarised in table 7. The CT for reconstituted blood with platelets stored for 1 day and PRBCs stored for 7 days was $135.3 \pm 19.7 \mathrm{~s}$, compared to $151.0 \pm 33.7 \mathrm{~s}$ for platelets stored for 5 days and PRBCs stored for 35 days. The CT obtained when fresh blood was studied was $224.7 \pm 103.1 \mathrm{~s}$. There was no statistically significant difference of the CT irrespective of the use of fresh or reconstituted whole blood.

Similarly, there was no difference between the CFT obtained using fresh whole blood and reconstituted whole blood. The CFT for reconstituted blood with platelets stored for 1 day and PRBC stored for 7 days was $84.0 \pm 36.5 \mathrm{~s}$, compared to $121.7 \pm 33.7 \mathrm{~s}$ for platelets stored for 5 days and PRBCs stored for 35 days. (table 8 ) The CFT obtained when fresh blood was studied was $74.5 \pm 18.3 \mathrm{~s}$.

There was no difference in MCF between fresh whole blood and reconstituted whole blood when using INTEM. The MCF for reconstituted blood with platelets stored for 1 day and red cells stored for 7 days was $68.5 \pm 2.7 \mathrm{~mm}$, compared to $58.0 \pm 5.6 \mathrm{~mm}$ for platelets stored for 5 days and red cells stored for 35 days (table 9). The MCF obtained when fresh blood was studied was $64.2 \pm 2.8 \mathrm{~mm}$. 
Table 1. CT results obtained using NATEM $($ mean $\pm \mathrm{SD})$

\begin{tabular}{|c|c|c|c|c|c|}
\hline \multirow[t]{3}{*}{ Storage days platelets } & \multicolumn{5}{|l|}{$\mathrm{CT}, \mathrm{s}$} \\
\hline & \multicolumn{5}{|c|}{ storage days PRBCs } \\
\hline & 7 & 14 & 21 & 28 & 35 \\
\hline 1 & $722.2 \pm 107.4$ & $700.5 \pm 102.4$ & $577.1 \pm 89.3$ & $579.4 \pm 130.6$ & $569.5 \pm 136.2$ \\
\hline 3 & $658.1 \pm 135.2$ & $596.0 \pm 162.1$ & $497.7 \pm 143.5$ & $486.0 \pm 130.8$ & $515.8 \pm 135.7$ \\
\hline 5 & $512.7 \pm 85.2$ & $527.9 \pm 214.7$ & $426.5 \pm 139.5$ & $387.1 \pm 73.0$ & $504.0 \pm 155.4$ \\
\hline
\end{tabular}

Table 2. CFT results obtained using NATEM $($ mean $\pm \mathrm{SD})$
Table 3. MCF results obtained using NATEM (mean \pm SD)
Table 4. CT results obtained using diluted innovin (modified EXTEM- see text) (mean \pm SD)
Table 5. CFT results obtained using diluted innovin (modified EXTEM, see text) $($ mean \pm SD)

Table 6. MCF results obtained using diluted innovin (modified EXTEMsee text) $($ mean \pm SD)

\begin{tabular}{llllll}
\hline Storage days platelets & \multicolumn{2}{l}{ CT, } \\
\cline { 2 - 6 } & \multicolumn{2}{l}{ storage days PRBCs } \\
\cline { 2 - 6 } & 7 & 14 & 21 & 28 & 35 \\
\hline 1 & $243.4 \pm 85.5$ & $100.2 \pm 74.7$ & $120.0 \pm 63.9$ & $121.6 \pm 47.2$ & $148.4 \pm 78.0$ \\
3 & $183.3 \pm 99.6$ & $102.0 \pm 50.3$ & $152.4 \pm 64.9$ & $132.2 \pm 39.1$ & $186.4 \pm 88.4$ \\
\hline & $110.3 \pm 187.6$ & $211.7 \pm 50.0$ & $161.2 \pm 44.1$ & $135.7 \pm 24.7$ & $168.0 \pm 63.6$ \\
\hline
\end{tabular}

\begin{tabular}{llllll}
\hline Storage days platelets & \multicolumn{2}{l}{ MCF, mm } \\
\cline { 2 - 6 } & \multicolumn{2}{l}{ storage days PRBCs } \\
\cline { 2 - 6 } & 7 & 14 & 21 & 28 & 35 \\
\hline 1 & $63.5 \pm 6.2$ & $58.0 \pm 4.4$ & $66.3 \pm 6.1$ & $65.6 \pm 3.5$ & $61.0 \pm 5.0$ \\
3 & $66.8 \pm 7.2$ & $60.7 \pm 5.0$ & $61.2 \pm 5.2$ & $58.3 \pm 7.7$ & $59.0 \pm 4.8$ \\
& $66.6 \pm 4.6$ & $63.9 \pm 3.3$ & $59.8 \pm 1.9$ & $55.3 \pm 6.9$ & $58.1 \pm 3.9$ \\
\hline
\end{tabular}

\begin{tabular}{llllll}
\hline Storage days platelets & \multicolumn{2}{l}{ CT, } \\
\cline { 2 - 6 } & \multicolumn{2}{l}{ storage days PRBCs } \\
\cline { 2 - 6 } & 7 & 14 & 21 & 28 & 35 \\
\hline 1 & $405.0 \pm 92.4$ & $350.6 \pm 57.1$ & $345.1 \pm 95.1$ & $360.0 \pm 110.9$ & $117.7 \pm 314.3$ \\
3 & $374.0 \pm 51.7$ & $344.7 \pm 88.8$ & $306.8 \pm 21.4$ & $298.1 \pm 74.8$ & $109.3 \pm 281.2$ \\
\hline & $339.2 \pm 38.4$ & $117.4 \pm 32.6$ & $289.5 \pm 50.6$ & $239.8 \pm 18.9$ & $218.5 \pm 55.1$ \\
\hline
\end{tabular}

\begin{tabular}{|c|c|c|c|c|c|}
\hline \multirow[t]{3}{*}{ Storage days platelets } & \multicolumn{5}{|l|}{ CFT, s } \\
\hline & \multicolumn{5}{|c|}{ storage days PRBCs } \\
\hline & 7 & 14 & 21 & 28 & 35 \\
\hline 1 & $120.5 \pm 29.3$ & $116.5 \pm 20.4$ & $114.0 \pm 33.4$ & $114.5 \pm 28.4$ & $114.6 \pm 61.8$ \\
\hline 3 & $118.3 \pm 33.8$ & $140.0 \pm 21.1$ & $97.8 \pm 25.3$ & $109.9 \pm 20.5$ & $103.9 \pm 34.7$ \\
\hline 5 & $133.4 \pm 26.9$ & $133.4 \pm 25.3$ & $103.9 \pm 12.1$ & $114.3 \pm 17.5$ & $125.6 \pm 36.7$ \\
\hline
\end{tabular}

\begin{tabular}{llllll}
\hline Storage days platelets & \multicolumn{2}{l}{ MCF, mm } \\
\cline { 2 - 6 } & \multicolumn{2}{l}{ storage days PRBCs } & & \\
\cline { 2 - 6 } & 7 & 14 & 21 & 28 & 35 \\
\hline 1 & $69.0 \pm 3.0$ & $62.8 \pm 3.7$ & $66.9 \pm 4.2$ & $65.9 \pm 2.8$ & $61.1 \pm 5.6$ \\
3 & $67.2 \pm 4.5$ & $63.0 \pm 4.5$ & $63.8 \pm 4.3$ & $62.1 \pm 4.2$ & $63.7 \pm 8.7$ \\
\hline
\end{tabular}


Table 7. CT

results obtained using INTEM $($ mean \pm SD)

Table 8. CFT

results obtained using INTEM (mean \pm SD)

Table 9. MCF

results obtained using INTEM $($ mean \pm SD)

\begin{tabular}{|c|c|c|c|c|c|}
\hline \multirow[t]{3}{*}{ Storage days platelets } & \multicolumn{5}{|l|}{$\mathrm{CT}, \mathrm{s}$} \\
\hline & \multicolumn{5}{|c|}{ storage days PRBCs } \\
\hline & 7 & 14 & 21 & 28 & 35 \\
\hline 1 & $135.3 \pm 19.7$ & $283.8 \pm 92.8$ & $333.6 \pm 71.8$ & $343.9 \pm 114.4$ & $118.2 \pm 26.5$ \\
\hline 3 & $110.8 \pm 27.3$ & $136.1 \pm 30.5$ & $295.2 \pm 78.2$ & $298.5 \pm 78.4$ & $137.4 \pm 32.2$ \\
\hline 5 & $121.7 \pm 24.1$ & $122.3 \pm 30.1$ & $285.7 \pm 58.5$ & $255.9 \pm 60.4$ & $151.0 \pm 33.7$ \\
\hline
\end{tabular}

\begin{tabular}{|c|c|c|c|c|c|}
\hline \multirow[t]{3}{*}{ Storage days platelets } & \multicolumn{5}{|l|}{ CFT, s } \\
\hline & \multicolumn{5}{|c|}{ storage days PRBCs } \\
\hline & 7 & 14 & 21 & 28 & 35 \\
\hline 1 & $84.0 \pm 36.5$ & $98.9 \pm 23.5$ & $104.1 \pm 18.2$ & $96.8 \pm 25.0$ & $84.9 \pm 35.1$ \\
\hline 3 & $97.3 \pm 41.3$ & $130.3 \pm 41.2$ & $103.7 \pm 18.6$ & $104.6 \pm 23.7$ & $110.7 \pm 49.3$ \\
\hline 5 & $94.0 \pm 23.8$ & $130.5 \pm 52.0$ & $109.2 \pm 18.3$ & $112.4 \pm 16.5$ & $121.7 \pm 33.7$ \\
\hline
\end{tabular}

\begin{tabular}{llllll}
\hline Storage days platelets & \multicolumn{2}{l}{ MCF, mm } \\
\cline { 2 - 6 } & \multicolumn{2}{l}{ storage days PRBCs } & & \\
\cline { 2 - 6 } & 7 & 14 & 21 & 28 & 35 \\
\hline 1 & $68.5 \pm 2.7$ & $66.5 \pm 9.6$ & $66.9 \pm 4.1$ & $65.5 \pm 5.3$ & $62.0 \pm 13.0$ \\
5 & $68.5 \pm 5.1$ & $64.8 \pm 2.9$ & $63.0 \pm 3.7$ & $60.7 \pm 4.6$ & $60.9 \pm 4.3$ \\
\hline
\end{tabular}

\section{Discussion}

In this study using TEG measurement by ROTEM, there was no difference in the haemostatic parameters measured between fresh whole blood and reconstituted whole blood using PRBCs stored for less than 21 days. However, it could be demonstrated that the CT was significantly shorter for reconstituted whole blood using red cells stored longer than 21 days when compared to fresh whole blood and whole blood reconstituted using PRBCs stored less than 21 days. We also showed an inverse correlation between the CT and the duration of storage of platelets used to reconstitute whole blood. The CFT was significantly shorter when whole blood reconstituted with PRBCs stored longer than 21 days was compared with fresh whole blood and whole blood reconstituted using PRBCs stored less than 21 days and remained unchanged with increasing duration of platelet storage. The MCF of fresh unrefrigerated blood was not different from that of reconstituted whole blood regardless of the duration of storage of red cells or platelets.

Our results suggest that fresh unrefrigerated whole blood does not provide any haemostatic advantage over stored blood products and, in addition, that storage of red cells and platelets under current blood bank conditions, may even result in an improvement of certain clotting parameters.
Red blood cells and platelets stored under standard blood bank conditions undergo deleterious changes that are collectively referred to as the 'storage lesion' [12]. Red blood cells preserved in conventional storage media have a shelf life of 35-42 days. During storage, intracellular levels of 2,3-diphosphosphoglycerol decline and concentrations of extracellular $\mathrm{H}^{+}$and $\mathrm{K}^{+}$ions increase, the latter as a result of impairment of the red cell $\mathrm{Na}^{+} / \mathrm{K}^{+}$and $\mathrm{Na}^{+} / \mathrm{H}^{+}$pumps and red cell haemolysis. It has been suggested that the combined effect of these changes confers a negative prognosis on patients receiving red cell units that were stored at $4{ }^{\circ} \mathrm{C}$ for prolonged periods. The effect of red cell storage on the activity of biochemical functions such as glycolysis and membrane structure and function has been well defined. Recently, storage of red cells has been shown to be associated with depletion of S-nitrososhemoglobin, resulting in depletion of nitric oxide bioactivity, a phenomenon that may have deleterious clinical effects after transfusion as a result of impaired hypoxic vasodilation [13]. Indeed, a number of studies have suggested that the transfusion of stored blood is associated with adverse clinical outcomes. Purdy et al. [14], in their retrospective study of 31 intensive care unit patients with severe sepsis, compared the age of blood products transfused in the subgroups of 19 patients who died and the 12 survivors. The median age of red cell units transfused in the surviving patients was significantly 
lower; hence, the authors of this study concluded that the age of red cells transfused correlated with patient mortality. While this conclusion may appear valid, a number of points are worth considering. First, the study design was retrospective; second, a small number of patients with various underlying diseases were studied; and, finally, the period over which patients were transfused was not considered in this study.

By contrast, Vamvakas and Carven [3] studied the relationship of length of storage with global morbidity after coronary artery bypass grafting. The mean ages of the oldest unit, the second oldest unit, and of all units transfused were determined and tested against surrogate measures of post-operative morbidity (length of intensive care stay, length of endotracheal intubation, and length of hospitalisation). No correlation between the age of the transfused units and overall morbidity was found in this prospective study. Another study performed in a paediatric population studied the effect of using fresh whole blood compared to reconstituted blood for pump priming in heart surgery in infants [4]. In this randomised, double-blind study, infants receiving fresh whole blood had longer intensive care unit admissions and increased post-operative fluid overload. Although the authors of this study could not provide an explanation for their findings, these results clearly demonstrate that there is no clear indication for the use of fresh whole blood in surgical patients. Indeed, the American Association of Blood Banks Guidelines for Massive Transfusion state that data are insufficient to require transfusion of fresher red cell units in cases of massive transfusion [15]. Likewise, Guidelines on the Management of Massive Blood Loss by the British Council on Standards in Haematology do not recommend transfusion of fresh blood becauseno evidence of decreased tissue oxygenation has been demonstrated in vivo after transfusion of older red cell units, despite the well documented in vitro storage lesion [16].

While the studies discussed above relate to physiologic and biochemical differences between fresh and stored red cells, no studies have specifically focused on the haemostatic properties of red cells and platelets stored under standard blood bank conditions. In our study, we used ROTEM, a technique that assess the overall kinetics and stability of clot formation and dissolution, to investigate the effects of storage time of red cells, platelets and plasma on haemostasis. Our findings of a potential haemostatic advantage of stored red cell and platelet units may be explained by the observation that during storage red cells and platelets showed a progressive increase in membrane phosphtidylserine expression that correlates with increased thrombin generation [17]. Furthermore, platelet storage is associated with microparticle formation that has a potent effect on thrombus generation and propagation [18]. This may explain why, in our study, blood products stored for a longer time induced shorter CTs. However, the correlation between in vivo haemostasis and in vitro TEG has not been established thus far.

Despite the fact that this study provided in vitro data that may not correlate with in vivo haemostasis, these results may have significance regarding the ongoing debate about the perceived superior haemostatic function of fresh, unrefrigerated whole blood and blood products stored for a shorter time in bleeding patients [19]. Apparently, the use of blood products in the clinical setting of massive haemorrhage is complex: numerous factors such as changes in body temperature, tissue perfusion, and circulating thromboplastin affect the coagulopathy of massive post-traumatic bleeding and make conclusions based on controlled laboratory studies unreliable. The role of TEG-guided therapy in massive blood loss is emerging, though not yet validated [20]. Our results may give rise to the more rigorous study of the presumed importance of fresh whole blood in severely bleeding patients.

\section{Conclusions}

ROTEM analysis performed in the current study demonstrates that clot formation was not impaired by storage of blood products. We found that blood products stored for a longer time induced shorter ROTEM CTs and CFTs. This may correlate with more rapid clot formation; nevertheless, the correlation between in vivo haemostasis and in vitro TEG has not been established thus far.

\section{Disclosure}

The authors declared no conflict of interest.

\section{References}

1 Erber WN, Tan J, Grey D, Lown JA: Use of unrefrigerated fresh whole blood in massive transfusion. Med J Aust 1996;165:11-13.

$\checkmark 2$ Repine TB, Perkins JG, Kauvar DS, Blackborne L: The use of fresh whole blood in massive transfusion. J Trauma 2006;60:S59-S69.

$\checkmark 3$ Vamvakes EC, Carven JH: Length of storage of transfused red cells and postoperative morbidity in patients undergoing coronary artery bypass graft surgery. Transfusion 2000;40:101-109.
4 Mou SS, Giroir BP, Molitor-Kirsch EA, Leonard SR, et al: Fresh whole blood versus reconstituted blood for pump priming in heart surgery in infants. N Engl J Med 2004;351:1635-1644.

5 Mallett SV, Cox DJA: Thromboelastography. Br J Anaesth 1992;69:307-313.

6 Gutensohn K, Geidel K, Kroeger N: Platelet function testing in apheresis products: flow cytometric, resonance thrombographic (RTG) and rotational thromboelastographic (roTEG) analysis. Transfus Apheresis Sci 2002;26:147-55.
7 Ganter MT, Hofer CK: Coagulation monitoring: current techniques and clinical use of viscoelastic point-of-care coagulation devices. Anesth Analg 2008;106:1366-1375.

8 Akay OM, Ustuner Z, Canturk Z, et al: Laboratory investigation of hypercoagulability in cancer patients using rotation thromboelastography. Med Oncol 2009;26:358-364. 
9 Young G, Ebessen LS, Viuff D, et al: Evaluation of thromboelastography for monitoring recombinant activated factor VII ex vivo in haemophilia A and B patients with inhibitors: a multicenter trial. Blood Coag Fibrinolysis 2008;19:276-282.

10 Shima M, Matsumoto T, Ogiwara K: New assays for monitoring haemophilia treatment. Haemophilia 2008;14(suppl 3):83-92.

11 Thromboelastometry. www.rotem.de/main/technology.html. Accessed October 26, 2010.

12 Hess JR, Greenwalt TG: Storage of red cells: new approaches. Transfus Med Rev 2002;16:283-295.

13 Reynolds JD, Ahearn GS, Angelo M, Zhang J, Cobb F, Stamler JS: S-nitrosohemoglobin deficiency: a mechanism for loss of physiological activity in banked blood Proc Natl Acad Sci U S A 2007;104:17058-17062.
4 Purdy FR, Tweeddale MG, Merrick PM: Association of mortality with age of blood transfused in septic ICU patients. Can J Anaesth 1997;44:1256-1261.

15 Bracey A, Harrison C, Weiskopf R, et al: Guidelines for Massive Transfusion. Bethesda, American Association of Blood Banks, 2005.

16 Stainsby D, MacLennan S, Thomas D, et al: Guidelines on the management of massive blood loss. $\mathrm{Br}$ J Haematol 2006;135:634-641.

17 Shapira S, Friedman Z, Radnay J, Ellis MH: The effect of storage on the expression of platelet membrane phosphatidylserine and subsequent impact on the coagulant function of stored platelets. Transfusion 2000;40:1257-1263.
18 Keuren JF, Magdeleyns EJ, Govers Riemsiag JW, et al: Effects of storage induced platelet microparticles on the initiation and propagation phase of blood coagulation. Br J Haematol 2006;134:307-313.

19 Spinella FC: Warm fresh whole blood transfusion for severe hemorrhage: U.S. military and potential civilian applications. Crit Care Med 2008; 36(suppl):S340-345.

20 Geeraedts LM Jr, Kaasjager HA, van Vugt AB, Frölke JP: Exsanguination in trauma: a review of diagnostics and treatment options. Injury 2009;40: 11-20. 